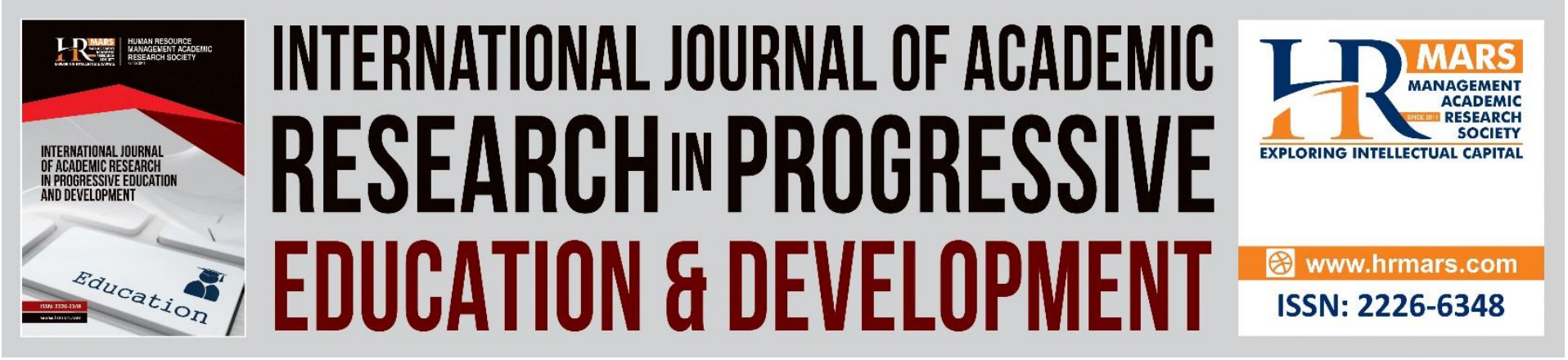

\title{
Understanding the Importance of Thinking Styles in Arabic Language Learning
}

Najmi Hayati, M. Ali Noer

To Link this Article: http://dx.doi.org/10.6007/IJARPED/v10-i4/11841

DOI:10.6007/IJARPED/v10-i4/11841

Received: 04 September 2021, Revised: 06 October 2021, Accepted: 25 October 2021

Published Online: 18 November 2021

In-Text Citation: (Hayati \& Noer, 2021)

To Cite this Article: Hayati, N., \& Noer, M. A. (2021). Understanding the Importance of Thinking Styles in Arabic Language Learning. International Journal of Academic Research in Progressive Education and Development, 10(4), 46-59.

Copyright: (C) 2021 The Author(s)

Published by Human Resource Management Academic Research Society (www.hrmars.com)

This article is published under the Creative Commons Attribution (CC BY 4.0) license. Anyone may reproduce, distribute, translate and create derivative works of this article (for both commercial and non-commercial purposes), subject to full attribution to the original publication and authors. The full terms of this license may be seen

at: http://creativecommons.org/licences/by/4.0/legalcode

\section{Vol. 10(4) 2021, Pg. 46 - 59}

\section{http://hrmars.com/index.php/pages/detail/IJARPED}

JOURNAL HOMEPAGE

Full Terms \& Conditions of access and use can be found at http://hrmars.com/index.php/pages/detail/publication-ethics 


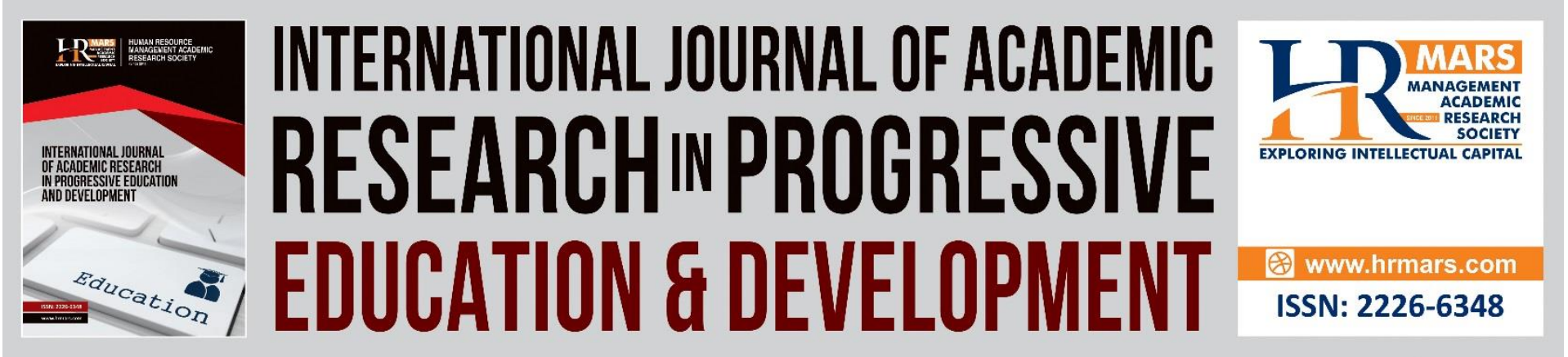

\title{
Understanding the Importance of Thinking Styles in Arabic Language Learning
}

\author{
Najmi Hayati, M. Ali Noer \\ Faculty of Islam, Universitas Islam Riau, Indonesia, Islamic Higher Education Directorate, The \\ Ministry of Religion, Indonesian Republic
}

\begin{abstract}
Students of the Ittihadul Muslim Islamic Boarding School in Pangkalan Pisang Village, Koto Gasib District, Siak Regency, Riau Province were asked to participate in this study to determine the association between their thinking style and their Arabic learning achievement. A total of 146 Madrasyah Aliyah 2nd grade students will be selected to participate in the survey. This study (1997) employed the Inventory Thinking Style Sternberg-Wagner research tool. Descriptive statistical analysis is used to determine the mean and standard deviations of a group of respondents in order to explain their profile and answer the research questions. His profile reveals that mean women score better on the thinking style scale than legislators, judges, anarchists, internal, liberal, and conservative candidates. It is more common for men to have Executive Thinking Styles such as Monarchy, Hirachy, Oligarchy, Local and External. This research also reveals the dominant thinking styles used by students in the Arabic learning class, including executive, judicial, monarchy, hirachy, oligarchy, anarchy, external, and conservative, as well as the dominating thinking styles used by students in the Arabic learning class. In every dominating Thinking Style, mean female students outperform mean male students by a significant margin. Legislative (Mean: 3.55 and SD: 0.649), Judicial (Mean: 3.80 and SD: 0.634), Anarchy (Mean: 3.71 and SD: 0.746), Internal (Mean: 3.58 and SD: 0.658), Liberal (Mean: 3.78 and SD: 0.624), and Conservative (Mean: $3.57 \&$ SD: 0.606). Because students and teachers have not fully grasped the sternberg thinking style, the comprehension that can be achieved in the classroom is still suboptimal when applying it.
\end{abstract}

Keywords: Sternberg, Thinking, Style, Learning, Student, Inventory.

\section{Introduction}

Learning that converts to students will be more directed. However, Isjoni (2007) stated that the system and technique in the learning process that the teacher employed, the majority of students still adopted the teacher's convict approach. To show care and to use the variances found in students as an advantage and a speciality that has positive implications for teaching and learning. This variation gives the perception of different learning styles in each individual student, which leads to changes in the planning and implementation of teachers and learning. Harmony between thinking style, learning style, and teaching style is required so that learning is more meaningful and leaves a positive effect on pupils. Students, according to Arsaythamby 
\& Hashim (2009), have their own ideas, the desire to study is constantly present, and they have a sense of responsibility to grasp their teachings. As a result, students will be motivated and their academic achievement will improve.

Someone's approach to a problem is referred to as their style (Zubaidah, 2010). Then someone's thinking style is the same as someone else's thinking style or the way someone else thinks. According to Fouladi \& Sahidi (2016), the Thinking Style is what describes the ability to process information in order to solve problems, and it has the potential to influence student academic accomplishment.

Each individual's Thinking Style is also influenced by information about information received in the brain and exhibited through behavior or speech utterances. Wanting a teacher should not see when their pupils lack the ability to learn, but rather the teacher should see in their students' way of thinking whatever they expect their teacher to see (Negahi, Nouri, \& Khoram, 2015). There is a link between thinking style and problem solving, decision making, and academic accomplishment (Negahi et al., 2015). As a result, Thinking Style is extremely significant and should be given special consideration in all parts of education in schools because it is a major role in forming an individual and boosting a student's academic performance. According to Ambotang (2014), pupils who are taught to think early on will be better able to follow the teaching and learning process. Someone's thinking style can be shaped and trained to produce the desired style by activities that are carried out or through experiences that are passed down to them.

\section{The Concept of Thinking Style}

Spearman (1927) says that thinking styles are derived from the tendency to sustain mental processes in the old occupation. According to him, these styles can be studied continuously in every situation. So that style can be fertilized and fertilized again through the activities conducted, and the development will be to resolve the problem.

Albrecht (1983) defines Thinking Style as a certain approach in which someone processes information, gains knowledge, forms ideas, applies values, solves issues, and expresses oneself. As a result of that item, thinking style is one of the variables that will fasten the academic learning student, which is the beginning of this interest in Thinking Style by the work of an American psychologist named Robert Sternberg (1988), who presents the notion of "mental self-government." The Thinking Style that was recommended in this study was based on the mental process of the four-dimensional cognitive tendencies, namely the concrete left brain, the abstract left brain, the concrete right brain, and the abstract right brain.

Sternberg (1997) proposes a theory of thinking style that views humans as beings who have the ability to choose and regulate their own lives. Control is exercised by the human mind, which has been compared to a government in that it regulates the procedures for individual existence inside an organization. Methods of thought this refers to what kids prefer to do and how they choose to do it (Betoret, 2007).

There are thirteen distinct thinking styles, which are classified according to five dimensions: function, shape, stage, scope, and tendency. Each individual's behavior is determined by his or her preferred mode of thought. When someone learns, creates, or receives something, replies, completes a task, or makes a decision, this behavior is demonstrated. Think Like an Instrument This study has been extensively used in a number of countries, including Hong Kong, China (Zhang (2001; 2004b; 2008a; 2008b), the Philippines (Bernardo, Zhang, \& Callueng, 2002), Spain (Betoret, 2007.; Cano-Garcia \& Hughes, 2000.; Liminana, Berna, \& 
Lopez, 2009), South Africa (Culliers \& Sternberg, 2001.; Murphy \& Janeke, 2009), the United States of America (Grigorenko \& Sternberg, 1997. Richmond, Krank \& Cummings, 2006), South Korea (Kim et al., 2007.; Lim, 2006.; Taman \& Choe, 2005.; Yun, 2005), Turki (Balkis \& Isiker, 2005) and Iran (Alborzi \& Ostovar, 2007), Brunei (Yong, 2012) As a result, it appears as though thinking with this instrument is quite simple to include in a variety of educational settings.

According to Sternberg (1997), the process of socialization can aid in the development of individual thinking styles by forming and strengthening them. Environmental elements have an impact on this type of fashion. There are five aspects that influence the formation of one's thinking style. A) Culture: When a culture supports and values something for its style, it encourages the style to evolve at a rapid pace, according to its people's experts. For example, in Japan, the community places a high value on tradition. Then it is a rising style that is both executive and conservative in nature. B) Gender; It has become ingrained in our minds that men make the rules and women follow them. Men are more likely to have a legislative thinking style, whereas women are more likely to have an executive thinking style. This inclination, on the other hand, can shift at specific moments. C) the individual's age; different stages of life might result in a variety of thinking processes. Low-law children are more likely to adopt a legislative style. However, while kids are in high school, they have a leaning toward executive thinking methods. This is due to the fact that their environment is more controlled and they must adhere to the rules and directions of their teachers. However, if someone is at the level of a university, they have a leaning toward the thinking styles of legislative, judicial, and liberalism. Individual interactions with their environment might therefore have an impact on the type of style that someone possesses. D) Parents and teachers: Children mimic what they see and hear. Older people or teachers, whether purposefully or unintentionally, have an impact on students based on their teaching approach. In this way, children's thinking styles are determined by the styles taught by their families and instructors. E) religion; religion or trust can have an impact on the formation of a person's thinking style. Some religions, such as the Jewish religion, encourage people to ask questions and get answers. The amount of trust that someone has will influence the development of their personal style.

What Sternberg has indicated is the same as what was stated by Piaget and Vygotsky in their theories of cognitive development and socio-cultural cognitive development, which stated that the formation of human cognition was influenced by biological and environmental factors. Activities or socialization processes that take place might either help to nurture or discriminate against specific styles. However, each style has its own set of advantages and disadvantages, which cause it to behave in a particular way or not be appropriate for a given context.

\section{Mindex Thinking Style Model (1983)}

A model of thinking based on the mental process of four-dimensional cognitive tendencies has been expressed by Albrecht (2011). The Mindex model is a model of thinking that is based on the mental process of four-dimensional cognitive tendencies that are divided into concrete right brains, concrete left brains, abstract right brains, and abstract left brains. It is stated that there are five basic thinking styles: synthesis, idealistic, pragmatic, analysts, and realists. A. Way of Thinking Synthesis tends to enjoy debate, controversy, and challenges, as well as the act of speculating. This style is more oriented toward innovative ideas. B) 
Idealistic thinkers have a proclivity for being attentive and receptive in their actions. They like to be adaptable to conflict and to think in a more holistic way. Those who subscribe to this style prefer to think about things in the long term and to focus on characteristics of humanity and its sentiments. C) Pragmatic thinking styles tend to be lighthearted and quick to reach conclusions. While producing something, they place a higher emphasis on the practical, innovative, and creative. D) Thinking style analysis indicates that the individual is calm, logical, disciplined, data-driven, systematic, and scientific in nature. The difficulty is broken down into smaller problems that can be solved by analyzing and interpreting data. They appreciate greater attention to detail, correctness, and perfection. E) Way of thinking Realists are brilliant, like concrete and structured things, are firm in their beliefs, and rely fully on their five senses to understand the world.

\section{Nedd Hermann Brain Quadrant Model (1993)}

Purwati (2016) describes Nedd Hermann's brain quadrant model (1993), which is based on the physical shape of the human brain. Human cognition can be classified into four moods: the left cerebral (analyzing analysis), right cerebral (imaginative thinking), left limbic (compiled thought), and right limbic (creative thought) (interpersonal thinking). Each quadrant represents a different way of thinking. Following the dominating part of the brain, four distinct kinds of thought emerged, which are as follows: a) Rational self (The Rational Self)-The left cerebral area is believed to be dominant, and individuals have a tendency to think in terms of analysis, critical thinking, realistic thinking, logic, and logic-based reasoning. A person's self-surrounding (the safe keeping) is governed by the dominant left limbic area, and they tend to think conservatively, methodically, and methodically. C) self-testing (the experimental self)-the dominating right cerebral area, and individuals have a tendency to think imaginatively, as well as a desire to experiment and take risks. When it comes to interpersonal relationships, emotion, and extroverts, the dominant right limbic portion, and individuals tend to think in terms of the feeling self (the Feeling Self), is the right limbic section.

In theory, this model explains how a person's thinking style is created as a result of the results of the learning process and the progression of age. This occurs when individuals concentrate their attention on portions of the brain that will become more prominent.

\section{Sternberg Model (1997)}

According to Governon's mental theory (Sternberg, 1997), a person's thinking style is defined as the manner in which they tend to approach work or conduct business. High IQ and abilities alone do not guarantee a person's success; rather, it is dependent on the Thinking Style that is possessed (Sternberg, 1997).

This hypothesis, as stated by Sternberg, can be utilized to identify thinking styles that are held by individuals in an organization of educational institutions and work organizations. Governon's mental theory expressed 13 thinking types spread over five dimensions, namely functions, forms, phases, scope, and the inclination of a government applied to individuals.

With respect to function dimensions (legislative, executive, and judiciary), there are three types of individual mental control functions, namely legislative, executive, and judicial styles. The legislative style individual prefers to engage in tasks that necessitate selfinstruction and self-direction, such as making their own rules and doing things their own way rather than following a predetermined path. Creating, making formulas, using creativity, and 
designing are some of their favorite activities. Individuals who have an executive style find greater satisfaction in carrying out tasks that are well defined. In contrast to people who have a legislative style, this executive style prefers to follow existing regulations by accomplishing something that has been determined first or that has been constructed first. Individuals with a judicial style pay close attention to the productivity evaluation of a particular task. They enjoy making assessments, conducting analyses, contrasting and justifying two opposing points of view. However, the body's ability to use Thinking Style is not simultaneous.

There are four types of government, each with its own dimensions of shape (monarchy, hirachy, oligarchy, and anarchy). These are monarchy, hirachy, oligarchy, and anarchy, and each has its own mental control of someone when doing chores. The monarchy approach is preferred by those who prefer to be involved in tasks that allow them to concentrate on a single problem at a time. They are motivated by the need to focus their thoughts and energies on a specific subject and are willing to overcome all hurdles in order to attain their goals. Individuals with this personality style do not excuse any disturbances that have the potential to prevent them from achieving their objectives. Hirachy, on the other hand, wants to prioritize numerous jobs at the same time, which is in opposition to Hirachy's method. They have the ability to accept multiple duties at the same time and properly evaluate the importance of these jobs, as well as to be systematic and judicious in the distribution of time according to virtue. They are aware of the most effective method for accomplishing a task. Oligarchy-style individuals enjoy completing a large number of chores and achieving a large number of goals in a short period of time, but they have difficulty deciding the priority of each task. All tasks have the same importance and objectives in their eyes. When they have completed the assignment or solved the problem, this can lead to conflict. Individuals with anarchy tendencies are also motivated by demanding tasks, but this can present difficulties at times due to the uncertainty in judging priority. This is due to the fact that they believe the regulations and procedures will be tough for them to follow. They would rather do something that they find enjoyable. Still, these individuals are intelligent in their use of and inclusion of ideas to answer an issue that may not be resolved by other people in the same way.

In terms of the stage's dimensions (global and local), there are two stages of Governon's mental control in this dimension, which are the global and local styles, respectively. Individuals that have a global style are more likely to give attention to big ideas, to be abstract, and to overlook anything that they consider to be insignificant. Individuals with local styles are more likely to be involved in jobs that entail specific and tangible issues, namely detailed tasks that do not view these issues in their entirety.

Individuals have two Governon mental control rooms, which are referred to as internal and external styles, depending on the scope of the scope (internal and external). Introverted people are more likely to be in charge of the internal style. They like a task that allows them to operate independently. Individuals who have more extroverted external styles, on the other hand, enjoyed being in groups and participating in the tasks that justified their participation. They also collaborated cooperatively with others.

There are two types of augmentation of mental control Governon of an individual, the liberal style and the conservative style, depending on the proportions of the propensity (liberal and conservative). Jobs that can lead to changes and entail the formulation of new ideas appeal to individuals with liberal personality styles. Maximum and boredom alterations to the normal surroundings are preferred by them since they provide them with 
independence that is not overly bound to the environment. Individuals with a conservative personality are more likely to adhere to the rules and procedures that are in place when doing their duties. They dislike sudden changes and prefer to remain in their familiar surroundings.

\section{Methodology}

Descriptive analysis is a technique for analyzing and explaining quantitative data (Weirsma, 2000). The information and data collected from the questionnaire in the form of raw scores will be examined using descriptive statistics and transformed into more easily understandable data (Hayes, 2000). Descriptive analysis is carried out in order to identify the frequency, mean, standard deviation, and percentage of each item performed, as well as the respondent's background information.

The mean value for student thinking styles is interpreted in accordance with the Mean norms established by Sternberg (1997), as shown in Table 3.1. For the purposes of this study, the dominant Thinking Style students were determined by comparing the total sample of the sample with the standard value of mean thinking style in the Inventory Thinking Style Sternberg (1997) handbook. The thinking style was judged to be the dominant thinking style in this study if its mean value was greater than the Sternberg standard value (1997). When the mean value of the study sample is low and straightforward, it is deemed to be a nondominant thinking style by the researchers.

\section{Results and Discussion}

According to gender data discovered in the field, there were 69 male pupils (47.3\%) and 77 female students $(52.7 \%)$. Taken from the second grade at the boarding school Madrasyah Aliyah Ittihadul Muslimin. 
INTERNATIONAL JOURNAL OF ACADEMIC RESEARCH IN PROGRESSIVE EDUCATION AND

DEVELOPMENT

Vol. 10, No. 4, 2021, E-ISSN: 2226-6348 @ 2021 HRMARS

Student Thinking Style Profile

Descriptive analysis that involves the mean and standard deviations is made to determine student thinking style profiles.

\begin{tabular}{|c|c|c|c|c|}
\hline & & Gendeı & & \\
\hline Dimension & Thinking style & Male & Female & Mean Higher \\
\hline & Executive & $\begin{array}{l}3.63 \\
0.611\end{array}$ & $\begin{array}{l}3.54 \\
0.619\end{array}$ & $\mathrm{~L}$ \\
\hline Function & Legislative & $\begin{array}{l}3.31 \\
0.620\end{array}$ & $\begin{array}{l}3.55 \\
0.649\end{array}$ & $P$ \\
\hline & Judisial & $\begin{array}{l}3.71 \\
0.652\end{array}$ & $\begin{array}{l}3.80 \\
0.634\end{array}$ & $\mathrm{P}$ \\
\hline & Monarchy & $\begin{array}{l}3.53 \\
0.663\end{array}$ & $\begin{array}{l}3.25 \\
0.622\end{array}$ & $\mathrm{~L}$ \\
\hline Chano & Hirachy & $\begin{array}{l}3.83 \\
0.596\end{array}$ & $\begin{array}{l}3.69 \\
0.623\end{array}$ & L \\
\hline Sllape & Oligarchy & $\begin{array}{l}3.55 \\
0.716\end{array}$ & $\begin{array}{l}3.43 \\
0.676\end{array}$ & $\mathrm{~L}$ \\
\hline & Anarchy & $\begin{array}{l}3.49 \\
0.627\end{array}$ & $\begin{array}{l}3.71 \\
0.746\end{array}$ & $P$ \\
\hline Stage & Global & $\begin{array}{l}3.24 \\
0.622\end{array}$ & $\begin{array}{l}3.11 \\
0.667\end{array}$ & $\mathrm{~L}$ \\
\hline Jage & Local & $\begin{array}{l}3.16 \\
0.672\end{array}$ & $\begin{array}{l}3.02 \\
0.691\end{array}$ & $\mathrm{~L}$ \\
\hline Scone & Internal & $\begin{array}{l}3.29 \\
0.692\end{array}$ & $\begin{array}{l}3.58 \\
0.658\end{array}$ & $P$ \\
\hline & External & $\begin{array}{l}3.57 \\
0.604\end{array}$ & $\begin{array}{l}3.35 \\
0.674\end{array}$ & $\mathrm{~L}$ \\
\hline & Liberal & $\begin{array}{l}3.64 \\
0.691\end{array}$ & $\begin{array}{l}3.78 \\
0.624\end{array}$ & $\mathrm{P}$ \\
\hline 11 & Conservative & $\begin{array}{l}3.29 \\
0.688\end{array}$ & $\begin{array}{l}3.57 \\
0.606\end{array}$ & $P$ \\
\hline
\end{tabular}

Table 4.2 Dimensions of thinking type, mean and standard deviation by gender, function, shape, stage, scope, and tendency

According to Table 4.2, the highest mean profile is a female student on Legislative Thinking Style (Mean: 3.55 and SD: 0.649), Judicial Thinking Style (Mean: 3.80 and SD: 0.634), Anarchy (Mean: 3.71 and SD: 0.746), Internal (Mean: 3.58 and SD: 0.658), Liberal (Mean: 3.78 and SD: 0.624), and Conservative (Mean: 3.78 and SD (Mean: 3.57 \& SD: 0.606). While male students had the greatest mean profile in Executive Thinking Style (Mean: 3.63 \& SD: 0.611), Monarchy (Mean: 3.53 \& SD: 0.663), Hirachy (Mean: 3.83 \& SD: 0.596), Oligarchy (Mean: 3.55 \& SD: 0.716), Local (Mean: 3.16 \& SD: 0.672) and External (Mean: 3.57 \& SD: 0.604). 
DEVELOPMENT

Vol. 10, No. 4, 2021, E-ISSN: 2226-6348 @ 2021 HRMARS

Male students had the lowest Profile of Means in the Legislative Thinking Style (Mean: 3.31 \& SD: 620), Judicial Thinking Style (Mean: 3.71 \& SD: 0.652), Anarchy Thinking Style (Mean: 3.49 \& SD: 0.627), Internal Thinking Style (Mean: 3.29 \& SD: 0.692), Liberal Thinking Style (Mean: 3.64 \& SD: 0.691), and Conservative Thinking Style (Mean: 3.29 \& SD: 3.29 \& SD: 3.29 \& SD: 3.29 \& SD: 3.89). While female students have the lowest mean profiles for Executive Thinking Style (Mean: 3.54 and SD: 0.619), Monarchy (Mean: 3.25 and SD: 0.622), Hirachy (Mean: 3.69 and SD: 0.623), Oligarchy (Mean: 3.43 and SD: 0.676), Global (Mean: 3.11 and SD: 0.667), Local (Mean: 3.02 and SD: 0.691), and External (mean: 3.35 \& SD: 0.674).

\section{Students With a Dominant Thinking Style}

Table 4.3 depicts a comparison between the mean thinking style of students and the mean thinking style of Sternberg (1997). A Mean-spirited Way of Thinking Students' responses to items in the Inventory of Thinking Style and Mean Thinking Style Dominant Sternberg (1997), which were extracted from the inventory handbook, are used to determine their grades.

According to the data in Table 4.3 below, the mean thinking style is executive, judicial, monarchy, hirachy, oligarchy, anarchy, external, and conservative, and the majority thinking style is oligarchy. While the Mean Thinking Style is the prevailing thinking style, the legislative, global, local, internal, and liberal thinking styles are all non-dominant thinking styles. For this dominant thinking style, the Sternberg scale was used to guide decision-making (1997).

\begin{tabular}{lllll}
\hline Thinking Style & $\mathbf{N}$ & Mean & Mean Dominant & Decision \\
\hline Executive & 146 & 3.59 & 3.57 & Dominant \\
Legislative & 146 & 3.43 & 4.00 & No \\
Judicial & 146 & 3.76 & 3.71 & Dominant \\
Monarchy & 146 & 3.39 & 3.14 & Dominant \\
Hirachy & 146 & 3.76 & 3.64 & Dominant \\
Oligarchy & 146 & 3.49 & 2.86 & Dominant \\
Anarchy & 146 & 3.60 & 3.57 & Dominant \\
Global & 146 & 3.18 & 3.21 & No \\
Local & 146 & 3.09 & 3.14 & No \\
Internal & 146 & 3.44 & 4.00 & No \\
External & 146 & 3.46 & 3.22 & Dominant \\
Liberal & 146 & 3.71 & 4.07 & No \\
Conservative & 146 & 3.43 & 3.07 & Dominant \\
\hline
\end{tabular}

Table 4.3 Students with Mean Thinking Styles and Mean Dominant Sternberg (1997)

\section{Conclusion}

Student Thinking Style Profile 
The results demonstrated that pupils were not confined by one of the 13 thinking types described by Sternberg-Wagner (1997). The mean value obtained shows that this style is used by all students. The study indicated that pupils used all styles at various phases. It supports the self-governing mind (Sternberg, 1997) notion of several thinking styles. According to Aljojo (2017) and (Liminana, Berna \& Lopez, 2009), students tend to employ all types of thinking styles learned, such as executives, legislature, judicial, monarchy, hierarchy, oligarchy, and anarchy. Students are not tied to one type of thinking and vice versa. This study's findings support Sternberg's (1997) theory that all styles think this is present in different styles in one profile.

\section{Student With a Dominant Thinking Style}

According to the findings of this study, pupils employ the dominant thinking style by utilizing executives, judiciary, monarchy, hirachy, oligarchy, anarchy, external, and conservative thinking styles. According to the dominant executive's style analysis, pupils have a strong tendency to obey, conform, and follow the rules and guidelines that have been set forth by the teacher. The findings of this study are consistent with the findings of the Aljojo (2017) study, which found that students used the dominant executive thought style while selecting activities and themes that were assigned by the teacher. The findings of this study are also consistent with the findings of prior investigations, such as those conducted by Bernardo (2002), Lim (2006), and other researchers (Liminana et al., 2009). As a result, the dominant executive's thinking style manifests itself in schooling in a dominant pattern.

Individuals who tend to evaluate something (Sternberg, 1997), such as students who are ranked in a university, are identified through a style analysis of dominant judicial thought. This individual devotes his or her time and attention to the evaluation of a profitable activity. They enjoy making judgments, being analytical, contrasting two points of view, and making decisions in general.

Observation of personal style Individuals who have a strong dedication to a single task are represented by the thinking dominant monarchy. The objective of these pupils is to finish one job in a specified amount of time in order to meet the requirements set by the teacher. According to Aljojo (2017), pupils that have this approach are extremely conscientious about repeating learning and making references in order to be able to master the best learning skills or content. The findings of this study corroborate the findings of other studies, such as those by Aljojo (2017); (Liminana et al., 2009), which found that monarchy thinking style was dominant among students.

Individuals who operate systematically and are composed are revealed by the style analysis of dominating Hirachy (Sternberg, 1997). This Hirachy style seeks to give importance to a number of monasteries at the same time. They have the ability to accept various assets in a sensible manner when choosing the priority of the assembly, to be systematic and wise when selecting the time based on its virtue.

Students' prevailing thinking pattern is oligarchy, according to a research analysis. Students that have these kinds of work habits prefer to do a small amount of work at a time. That is, students that learn in an oligarchy manner can read, take notes, and do tasks all at the same time. Students are expected to behave in an oligarchy-like manner as a result of their participation in numerous activities over a period of time. The findings of this study are consistent with the findings of Lim (2006); Aljojo (2017), who found that pupils require this form of thought oligarchy in order to finish a large number of tasks within a short period of 
time. However, the tendency to adopt this style is less important than the quality of the product or the results of the job that has been generated because students may lose focus on the actual purpose in order for the order of origin to be resolved.

According to the findings of the research, the external dominating thinking style in these kids has a high predisposition to socialize, to be outgoing when meeting new people, and to have excellent interpersonal skills. According to Piaget's theory of development, kids who are in their adolescent years like socializing in their groups in order to discover their own identities. Students enjoy socializing and expressing their viewpoints, which means that teachers should take advantage of this opportunity to direct students to learn jointly, which not only allows students to develop their creativity, but also allows them to develop their personality. For example, kids learn to respect others, to be more receptive to criticism or rebuke, and to maintain beliefs that have merit.

Furthermore, the style analysis of conservative dominating thinking among students was investigated. These kids have a tendency to adhere to outdated processes. This defines the circumstance in which the learning that takes place in classrooms tends to follow the course outline that has been established in the syllabus. According to Fouladi \& Shahidi (2016), it is a conventional method. For example, when students do experiments in Arabic, less emphasis is placed on the development of student creativity in the process of experimenting. Students only do experiments if they follow all of the protocols that have been established to demonstrate a concept (Balkis \& Isiker, 2005). As a result, this type of teaching and learning does not encourage the development of more creative and innovative ideas. This is a propensity for conservative thinking styles to prevail. In accordance with the perspective of Aljojo (2017), who argues that this habit element supports positive behaviors to comply with all of the regulations and inputs provided.

\section{Acknowledgement}

The author wishes to express his heartfelt appreciation to the Directorate of Islamic Higher Education and the Directorate General of Islamic Education of the Ministry of Religious Republic of Indonesia for their assistance in Cluster Basic Research Interdisciplinary at MTs Ittihadul Muslim Pesantren under Budget Year 2021. 


\section{References}

Albrecht, K. (1983). Organization Development: A Total Systems Approach to Positive Change in Any Business Organization. Englewood Cliffs. New Jersey: Prentice Hall.

Albrecht, K. (2011). Mindex Theory: Thinking Styles. Available online at: https://www.karlalbrecht.com/mindex/mindextheory.html

Alborzi, S., \& Ostovar, S. (2007). Thinking Styles Of Gifted And Non-Gifted Students In Iran. Psychological Reports, 2(100), 1076-1082.

Aljojo, N. (2017). Differences In Styles Of Thinking 'In Light Of Sternberg's Theory': A Case Study Of Different Educational Levels In Saudi Arabia. Journal of Technology and Science Education JOTSE, 7(3), 333-346, 2014-5349. https://doi.org/10.3926/jotse.291.

Ambotang, A. S. (2014). Menerapkan Kemahiran Berfikir. Minda Pendidikan. http://eprints.ums.edu.my/8398/1/nc0000003879.pdf. Accessed 23 October, 2020

Arsaythamby, V., \& Rosna A. H. (2009). Kesahan Dan Kebolehpercayaan Alat Ukur Orientasi Pembelajaran Matematik (OPM). International Journal of Management Studies, 16(1), 57-73.

Balkis, M., \& Isiker, G. B. (2005). The Relationship Between Thinking Styles And Personality Types. Social Behaviour and Personality: an International Journal, 33(3), 283-294.

Betoret, F. D. (2007). The Infl Uence Of Students' And Teachers' Thinking Styles On Student Course Satisfaction And On Their Learning Process. An International Journal of Experimental Educational Psychology, 27(2), 219-234.

Bernardo, A. B., Zhang, L. F., \& Callueng, C. M. (2002). Thinking Styles And Academic Achievement Among Filipino Students. The Journal of Genetic Psychology, 163, 149163.

Yong, B. C. S. (2012). Comparison Between The Thinking Styles Of Students In A Science School And A Mainstream School. Journal Of Science And Mathematics Education In Southeast Asia 2012. Vol. 35 No. 1, $60-83$.

Cano-Garcia, F., \& Hughes, E. H. (2000). Learning And Thinking Styles: An Analysis Of Their Interrelationship And Infl Uence On Academic Achievement. An International Journal of Experimental Educational Psychology, 20, 413-430.

Culliers, M., \& Sternberg, R. J. (2001). Thinking Styles: Implications For Optimizing Learning And Teaching In University Education. South African Journal of Health Education, 15, 13-24.

Purwati, E. (2016). Optimalisasi Pendidikan Islam melalui Pembelajaran Berbasis Cara Kerja Otak. Jurnal Studi Kelslaman ISLAMICA. VOL. 11 NO. 1 (2016). Universitas Islam Negeri Sunan Ampel Surabaya. https://doi.org/10.15642/islamica.2016.11.1.86-112

Fouladi, N., \& Shahidi, E. (2016). Creativity, Thinking Style And Mental Disorders. Journal of Fundamental and Applied Sciences, 8(2),1726-1736. https://doi.org/10.4314/jfas.v8i2s.110

Grigorenko, E. L., \& Sternberg, R. J. (1997). Styles Of Thinking, Abilities, And Academic Performance. SAGE Journals: Exceptional Children, 63, 295-312. https://doi.org/10.1177/001440299706300301

Hayes, N. (2000). Doing Psychological Research: Gathering And Analyzing Data/Nicky Hayes. ISBN 0-335-20379-5 (pbk.) 1. Psychology-Research- Methodology.

Isjoni. (2007). Saatnya Pendidikan Kita Bangkit. Yogyakarta: Pustaka Siswa 
Kim, Y., Seo, J. H., Kim, J. M., \& Lee, W. G. (2007). Suggestions For Effective Teaching Methods Through Analysis Of The Learning And Thinking Styles Of Gifted IT Students. WSEAS Transactions on Advances in Engineering Education, 11(4), 228-237.

Liminana, R. M., Berna, J. C., \& Lopez, P. S. (2009). Thinking Styles And Coping When Caring A Child With Severe Spina Bifi Da. Journal of Development and Physical Disabilities, 21, 169-183.

Lim, S. H. (2006). Differences In Thinking Styles And Learning Styles Between Gifted Students Of Each Area At Middle Schools And Average Students (Unpublished Master's Thesis). Pukyung National University Graduate School of Education, Korea.

Lumsdaine, E., \& Lumsdaine, M. (1995). Creative Problem Solving. IEEE Potentials, 13(5), 4-9. doi:10.1109/45.464655

Murphy, A., \& Janeke, H. C. (2009). The Relationship Between Thinking Styles And Emotional Intelligence: An Exploratory Study. South African Journal of Psychology, 39(3), 357375.

Negahi, M., Nouri, N., \& Khoram, A. (2015). The Study of Learning Styles, Thinking Style, and English Language Academic Self-Efficacy Among the Students of Islamic Azad University of Behbahan Considering Their Field of Study and Gender. Theory and Practice in Language Studies, 5(8), 1722-1729. http://doi.org/10.17507/tpls.0508.25

Park, S. K., Park, K. H., \& Choe, H. S. (2005). The Relationship Between Thinking Styles And Scientifi C Giftedness In Korea. The Journal of Secondary Gifted Education, 16(2/3), 8797.

Richmond, A. S., Krank, H. M., \& Cummings, R. (2006). A Brief Research Report: Thinking Styles Of Online Distance Education Students. International Journal of Technology in Teaching and Learning, 2(1), 58-64.

Slavin, R. E. (2006). Educational Psychology: Theory and Practice ( $8^{\text {th }}$ ed.). Boston: Pearson Spearman, C. (1927). The Measurement Of Intelligence. Nature 120, 577-578 (1927). No.3025 Vol.120 doi: https://doi.org/10.1038/120577a0

Sternberg, R. J. (1997). Thinking Styles. New York: Cambridge Universiti Press. https://doi.org/10.1017/CBO9780511584152

Sternberg, R. J. (2012). The Assessment of Creativity: An Investment-Based Approach. Creativity Research Journal, 24(1), 3-12. https://doi.org/10.1080/10400419.2012.652925

Sternberg, R. J., \& Grigorenko, E. L. (1993). Thinking Styles and The Gifted. Roeper Review, 16(2), 122-130. https://doi.org/10.1080/02783199309553555.

Sternberg, R. J., \& Grigorenko, E. L. (1995). Styles Of Thinking in The School 1. European Journal For High Ability, 6(2), 201-219. https://doi.org/10.1080/0937445940060211

Sternberg, R. J., \& Grigorenko, E. L. (1997). Are Cognitive Styles Still In Style?. American Psychologist, 52(7), 700. https://doi.org/10.1037/0003-066X.52.7.700

Sternberg, R. J., \& Grigorenko, E. L. (2001). A Capsule History of Theory and Research on Styles. In R. J. Sternberg \& L. F. Zhang (Eds.), Perspectives on Thinking, Learning and Cognitive Styles. Mahwah, NJ: LEA. University.

Sternberg, R. J., \& Zhang, L. (2001). Perspectives On Thinking, Learning and Cognitive Styles. The Educational Psychology Series (pp. 197-226). Mahwah, NJ: Lawrence Erlbaum.

Sternberg, R. J. (1988). Mental Self-Government: A Theory Of Intellectual Styles And Their Development. Human Development, 31, 197-224. 
Meerah, T. S. (2009). Teacher's behavior and knowledge for enhancing student's achievement. Dlm. Onno De Jong \& Lilia Halim. (Penyt), Teachers' Professional Knowledge in Science and Mathematics Education: Views From Malaysia and Abroad, Bangi: Universiti Kebangsaan Malaysia.

Weirsma, W. (2000). Research Methods In Education. Boston: Allyn and Bacon Williams,W. 2008. The Relationship Between Parenting Practices, Socioeconomic Status, and Ethnicity to the Academic Achievement of High School Students. Accessed http://www.allfreeessays.com/essays/Relationship-Between-

ParentingPracticesSoeconomic-Status/11502.html. Dicapai pada 12/5/2013

Yun, S. H. (2005). Study On Teaching-Learning Methods By Thinking Styles Of Gifted IT Students (Unpublished Master's Thesis). Korea National University of Education, Korea.

Zhang, L. F. (2002). Thinking Styles: Their Relationships With Modes Of Thinking And Academic Performance. Educational Psychology, 22(3)

Zhang, L. F. (2001). Approaches And Thinking Styles In Teaching. Journal of Psychology, 135: $547-561$.

Zhang, L. F. (2006). Thinking Styles And The Big Five Personality Traits Revisited. Journal of Personality and Individual Differences, 40, 1177-1187.

Zhang, L. F., \& Sternberg, R. J. (2000). Are Learning Approaches And Thinking Styles Related? A Study In Two Chinese Populations. The Journal of Psychology: Interdisciplinary and Applied, 134(5):469-489

Zhang, L. F., \& Sternberg, R. J. (2002). Thinking Styles And Teachers' Characteristics. International Journal of Psychology. 37 (1): 3-12

Zhang, L. F. (2001). Do Thinking Styles Contribute To Academic Achievement Beyond SelfRated Abilities?. The Journal of Psychology, 135(6), 621-637.

Zubaidah, S. (2010). Berpikir Kritis Kemampuan Berpikir Tingkat Tinggi Yang Dapat Dikembangkangkan Melalui Pembelajaran Sains. Optimalisasi Sains Untuk Memberdayakan Manusia di Pascasarjana Universitas Negeri Surabaya, 16, 1-14. 